\title{
Sustained Activation of Toll-Like Receptor 9 Induces an Invasive Phenotype in Lung Fibroblasts
}

\section{Possible Implications in Idiopathic Pulmonary Fibrosis}

\author{
Varvara Kirillov, ${ }^{*}$ Jonathan T. Siler, ${ }^{*}$ Mahalakshmi Ramadass, ${ }^{*}$ Lingyin Ge, ${ }^{*}$ James Davis, ${ }^{*}$ Geraldine Grant, \\ Steven D. Nathan, ${ }^{\ddagger}$ Gabor Jarai, ${ }^{\S}$ and Glenda Trujillo*
}

From the Department of Pathology, * Stony Brook University School of Medicine, Stony Brook, New York; the Department of Molecular and Microbiology, School of Systems Biology, George Mason University, Fairfax, Virginia; the Advanced Lung Disease and Transplant Program, ${ }^{\ddagger}$ Inova Fairfax Hospital, Falls Church, Virginia; and the Respiratory Disease Area, ${ }^{\S}$ Novartis Institutes for Biomedical Research, Horsham, United Kingdom

\author{
Accepted for publication \\ December 29, 2014. \\ Address correspondence to \\ Glenda Trujillo, Ph.D., Fibrotic \\ Diseases Drug Discover, \\ Bristol-Myers Squibb, 311 \\ Pennington-Rocky Hill Rd, \\ Pennington, NJ 08534. E-mail: \\ glenda.trujillo@bms.com.
}

\begin{abstract}
Idiopathic pulmonary fibrosis (IPF) is characterized by excessive scarring of the lung parenchyma, resulting in a steady decline of lung function and ultimately respiratory failure. The disease course of IPF is extremely variable, with some patients exhibiting stability of symptoms for prolonged periods of time, whereas others exhibit rapid progression and loss of lung function. Viral infections have been implicated in IPF and linked to disease severity; however, whether they directly contribute to progression is unclear. We previously classified patients as rapid and slow progressors on the basis of clinical features and expression of the pathogen recognition receptor, Toll-like receptor 9 (TLR9). Activation of TLR9 in vivo exacerbated IPF in mice and induced differentiation of myofibroblasts in vitro, but the mechanism of TLR9 up-regulation and progression of fibrosis are unknown. Herein, we investigate whether transforming growth factor (TGF)- $\beta$, a pleiotropic cytokine central to IPF pathogenesis, regulates TLR9 in lung myofibroblasts. Results showed induction of TLR9 expression by TGF- $\beta$ in lung myofibroblasts and a distinct profibrotic myofibroblast phenotype driven by stimulation with the TLR9 agonist, CpG-DNA. Chronic TLR9 stimulation resulted in stably differentiated $\alpha$-smooth muscle actin ${ }^{+} /$platelet-derived growth factor receptor $\alpha^{+} / \operatorname{CD}_{4} 4^{+} /$matrix metalloproteinase- $14^{+} /$matrix metalloproteinase- $2^{+}$myofibroblasts, which secrete inflammatory cytokines, invade Matrigel toward platelet-derived growth factor, and resist hypoxia-induced apoptosis. These results suggest a mechanism by which TGF- $\beta$ and TLR9 responses in myofibroblasts collaborate to drive rapid progression of IPF. (Am J Pathol 2015, 185: 943-957; http://dx.doi.org/10.1016/j.ajpath.2014.12.011)
\end{abstract}

Idiopathic pulmonary fibrosis (IPF) is a fatal interstitial lung disease with an unknown cause and limited treatment options. The most widely accepted model for IPF pathogenesis is that persistent injury to the alveolar epithelium promotes a chronic inflammation that sustains uncontrolled activation and proliferation of fibroblasts. ${ }^{1}$ Many different cell types appear to participate in this process, including fibroblasts, cells of hematopoietic origin (macrophages and lymphocytes), and lung epithelial cells. Interestingly, although a characteristic feature of IPF is the presence of increased fibroblasts and myofibroblasts, the origin of these mesenchymal cells remains uncertain and has been the subject of recent controversy. ${ }^{1}$
Possibilities include proliferation and differentiation of resident lung fibroblasts, recruitment of the bone marrow-derived progenitor cells (fibrocytes), and transformation of lung epithelial cells and pericytes to mesenchymal cells by the

\footnotetext{
Supported by Novartis Institutes for Biomedical Research in collaboration with Dr. Gabor Jarai, Head of Remodeling, Respiratory Diseases, at Novartis.

Disclosures: S.D.N. has been a consultant on the subject of idiopathic pulmonary fibrosis for Bayer Pharmaceuticals and Boerhinger-Ingelheim. G.T. is a coinventor on a US Provisional Patent Application Series No. 61/ 258293, entitled Biomarkers Predictive of Progression of Fibrosis, with Novartis and The University of Michigan. G.J. is employed by Novartis.

Current address of G.T. and G.J., Bristol-Myers Squibb, Hopewell, NJ.
} 
process of epithelial-to-mesenchymal transition. The excessive scarring in IPF is attributed to activation, proliferation, and differentiation of myofibroblasts, mostly mediated by the profibrotic cytokine, transforming growth factor (TGF)- $\beta .^{2}$ In the lung, various cells can produce TGF- $\beta$, and lung tissue levels are elevated in both human IPF patients and animal models of pulmonary fibrosis. Moreover, TGF- $\beta$ alone is sufficient to induce progressive fibrosis in some animal models. ${ }^{3}$ Although TGF- $\beta$ is fundamental for the pathogenesis of fibrosis, it cannot be targeted therapeutically because of its numerous pleiotropic functions. ${ }^{2}$ Thus, investigating effector pathways downstream of TGF- $\beta$ is a more selective approach to identify critical checkpoints that may determine the clinical course in IPF.

The management of IPF is currently unsatisfactory, not only because of the lack of effective therapies but also because the clinical course among patients is unpredictable and highly variable. Although some patients demonstrate steady progression of the disease over time, a subset of patients experience an acute episode of rapid deterioration in pulmonary function, the cause of which is not known. It is also not clear whether these acute exacerbations of IPF represent a primary acceleration of the underlying fibroproliferative process or are a distinct secondary complication possibly due to an infection. ${ }^{4}$ Our group and others have previously investigated the link between acute exacerbations and the rapidly progressive phenotype in IPF patients. ${ }^{5-7}$ Previously, we defined a clinical subset of patients that demonstrates rapid deterioration of lung function and a significantly increased mortality rate (rapid progressors) and further identified that the innate immune receptor Toll-like receptor 9 (TLR9) was strongly associated with this aggressive variant of IPF. ${ }^{8}$

The TLR system is a primary innate immune recognition mechanism that permits cells to detect common pathogenassociated molecular patterns on infectious agents. TLR9 recognizes oligodeoxynucleotides containing unmethylated CpG motifs that are present in bacterial and viral DNA. ${ }^{9-11}$ Herpes viruses, specifically $\gamma$ herpes viruses Epstein-Barr virus and Kaposi sarcoma associated herpesvirus, have been detected in the lungs of IPF patients and may be causally related to the development of IPF. ${ }^{10-12}$ Recent evidence has demonstrated that $\gamma$ herpes viruses interact with TLR9 directly. ${ }^{13-15}$ Moreover, we have demonstrated elevated TLR9 expression in lung biopsy specimens from IPF patients classified as rapid progressors versus normal subjects or those classified as stable progressors. We have also shown that human IPF lung fibroblasts cultured from surgical biopsy specimens demonstrate increased myofibroblast differentiation when stimulated with CpG-DNA in vitro. Nevertheless, numerous questions remain regarding the exact role of TLR9 in mediating fibrogenesis independent of its innate immunity function. TGF- $\beta$ has a pivotal role in fibrosis by driving upregulation of collagen synthesis, epithelial-to-mesenchymal transition, and myofibroblast differentiation. ${ }^{2,16}$ Establishing a link between distinct TGF- $\beta$ triggered signal transduction pathways, and activation of TLR9 is important for gaining further insights into the development of the TLR9 $9^{\mathrm{Hi}}$ myofibroblast phenotype. TLR9 is a member of the dangerassociated molecular pattern receptor family that functions as a sensor for pathogenic DNA. Originally identified as a receptor on immune cells for exogenous pathogens, its potential role in sterile (noninfectious) inflammation has been highlighted recently. ${ }^{17}$ TLR9 is widely expressed in immune, epithelial, and mesenchymal cells., ${ }^{918}$ The mechanism by which TLR9 mediates the rapid acceleration of IPF remains unclear. Furthermore, it is not known whether TLR9 expression and/or activation is regulated by the pleiotropic profibrotic cytokine TGF- $\beta$.

Recently, the concept of IPF as a cancer-like disease has been brought to the forefront. Indeed, epigenetic and genetic abnormalities, altered cell-to-cell communications, uncontrolled proliferation, and abnormal activation of specific signal transduction pathways are biological hallmarks that characterize the pathogenesis of IPF and cancer alike. ${ }^{19} \mathrm{Li}$ et $\mathrm{al}^{20}$ recently demonstrated that an invasive fibroblast phenotype in IPF is mediated by hyaluronan and its major cell surface receptor, CD44. Cumulative evidence suggests that IPF fibroblasts may acquire properties similar to metastatic cancer cells. ${ }^{21}$ Herein, we report a similar induction of an invasive fibroblast phenotype mediated by TLR9. Characteristics of CpG-DNA-differentiated fibroblasts include invasiveness through Matrigel, high expression of $\alpha$ smooth muscle actin $(\alpha \mathrm{SMA})$, platelet-derived growth factor receptor (PDGFR), matrix metalloproteinase (MMP)-14, and active MMP-2, and resistance to hypoxia-induced apoptosis. Moreover, we report that TGF- $\beta$ positively regulates TLR9 expression, producing profibrotic TLR $9^{\mathrm{Hi}}$ myofibroblasts that are highly responsive to CpG DNA. Collectively, our data provide evidence for a mechanism explaining TLR9-mediated rapid progression of IPF via the activation of an invasive fibroblast phenotype driven by TLR9.

\section{Materials and Methods}

\section{Cell Culture and Reagents}

Primary pulmonary normal human lung fibroblast (NHLF) lines $(n=2)$ (Lonza, Walkersville, MD) were grown in Dulbecco's modified Eagle's medium (DMEM) supplemented with $10 \%$ fetal bovine serum (FBS) and $1 \%$ penicillin/streptavidin (Gemini, West Sacramento, CA) in a humidified 5\% $\mathrm{CO}_{2}$ atmosphere at $37^{\circ} \mathrm{C}$. Before treatment, cells were serum starved overnight. Cells were stimulated with 0.1 to $10 \mathrm{ng} / \mathrm{mL}$ TGF- $\beta$ (R\&D Systems, Minneapolis, MN) or $50 \mu \mathrm{g} / \mathrm{mL} \mathrm{CpG-}$ DNA (HyCult, Plymouth Meeting, PA) for indicated times.

\section{IPF Fibroblasts}

IPF tissue was procured from the explanted lungs of patients undergoing lung transplantation at Inova Fairfax Hospital (Falls Church, VA), and with the approval of Inova Health System and George Mason University (Fairfax, VA) 
Institutional Review Boards. Normal $(n=4)$ and IPF fibroblasts $(n=4)$ were isolated by differential binding after enzymatic dissociation, as previously described. ${ }^{22-27}$ Specifically, all samples were dissected into 1- to $2-\mathrm{mm}^{2}$ pieces at $4^{\circ} \mathrm{C}$ in phosphate-buffered saline (PBS) and subjected to enzymatic digestion in $0.4 \%$ collagenase $\mathrm{P}$ (Roche, Indianapolis, IN) in complete media (DMEM) containing $10 \%$ FBS, $100 \mathrm{IU} / \mathrm{mL}$ penicillin, $100 \mu \mathrm{g} / \mathrm{mL}$ streptomycin, $0.25 \mu \mathrm{g} / \mathrm{mL}$ amphotericin $\mathrm{B}$, and $0.1 \%$ DNase 1 , at $37^{\circ} \mathrm{C}$ in a humidified 5\% $\mathrm{CO}_{2}$ incubator for 2 hours. The resulting cells were seeded in complete media onto tissue culturetreated plastic and incubated at $37^{\circ} \mathrm{C}$ and $5 \% \mathrm{CO}_{2}$ for 45 minutes. After 45 minutes, the attached fibroblast cells were washed vigorously with sterile PBS and continued in culture. The fibroblast identity of these cells was confirmed by immunocytochemistry in both the 45-minute differential binding population and the same population after exposure to cell culture for 120 hours. Cells were tested for the presence of anti-human actin ( $\alpha$ SMA; Ab7817; fibroblast; Abcam, Cambridge, MA), anti-human cytokeratin 18 (Ab668; epithelial; Abcam), anti-human CDllb (Ab52478; monocyte/macrophage; Abcam), and anti-human von Willebrand factor (Ab68545; endothelial). The percentage of positively stained cells was determined by counting the total number of cells in five random fields in addition to the total number of positive cells for each antibody. The IPF fibroblast population was virtually free of contaminating epithelial cells (cytokeratin 18 negative: $1.80 \% \pm 0.67 \%$ ), monocytes/macrophages (CD11b), and endothelial cells (von Willebrand factor). Detailed analyses demonstrated that the IPF fibroblasts were positive for $\alpha$-SMA $(99.80 \% \pm 0.24 \%)$ staining in populations immediately after isolation.

\section{Human Lung Tissue}

Non-IPF (chronic obstructive pulmonary disease/emphysema) (forced expiratory volume in 1 second \% of predicted, $>=80$ ) control and usual interstitial pneumonia/ IPF (forced expiratory volume in 1 second \% of predicted, $<50$ and 50 to 80) frozen lungs in RNAlater (Life Technologies, Norwalk, CT) and slides were obtained from the University of Colorado Denver (Denver, CO), NIH Lung Tissue Research Consortium. Sample processing conformed to Lung Tissue Research Consortium guidelines. Normal (non-IPF) human tissue samples from Stony Brook University (Stony Brook, NY) Department of Pathology were deidentified and categorized as medical waste; therefore, they were not considered human subject research and were exempt from the Stony Brook University Institutional Review Board review.

\section{Western Blot Analysis}

NHLFs were lysed in buffer $\left(6.1 \mathrm{mmol} / \mathrm{L} \mathrm{Na}_{2} \mathrm{HPO}_{4}, 4.5\right.$ $\mathrm{mmol} / \mathrm{L} \mathrm{NaH}{ }_{2} \mathrm{PO}_{4}, 88.4 \mathrm{mmol} / \mathrm{L} \mathrm{NaCl}, 36.6 \mathrm{mmol} / \mathrm{L} \mathrm{LiCl}$,
$36.6 \mathrm{mmol} / \mathrm{L} \mathrm{SDS}, 24.1 \mathrm{mmol} / \mathrm{L}$ sodium deoxycholate, and $1 \%$ Triton X-100) and complete protease inhibitor cocktail (Roche). Cell debris was removed by centrifugation, and supernatants were denatured at $100^{\circ} \mathrm{C}$ in Tris-glycine SDS sample buffer. Protein samples $(10 \mu \mathrm{g})$ were subjected to electrophoresis on a $10 \%$ reducing SDS-PAGE gel (Bio-Rad) and blotted onto a nitrocellulose or polyvinylidene difluoride membrane (Bio-Rad Laboratories Incorporated). Membranes were blocked for 2 hours to overnight in Tris-buffered saline, $0.1 \%$ (v/v) Tween-20, and 5\% (w/v) nonfat dried milk. Immunodetection was performed using anti-TLR9 (Abcam), anti- $\alpha$ SMA (Abcam), anti-PDGFR $\alpha$ (Cell Signaling), anti-MMP-14 (Abcam), anti-fibronectin (Abcam), anti-CD44 (Santa Cruz Biotechnology, Dallas, TX), anti-cleaved caspase-3 (Cell Signaling, Danvers, MA), and anti-glyceraldehyde-3-phosphate dehydrogenase (Santa Cruz Biotechnology). The protein bands were visualized using the ECL system (Denville Scientific, South Plainfield, NJ). All Western blot densitometry data are normalized for the loading control, glyceraldehyde-3phosphate dehydrogenase.

\section{Matrigel Invasion Assay}

The invasive behavior of NHLFs was performed essentially as described previously. ${ }^{20}$ Equal numbers of fibroblasts were plated onto the BioCoat Matrigel Invasion Chamber (BD Biosciences, San Jose, CA), and the cell invasion was performed in the presence of $20 \mathrm{ng} / \mathrm{mL}$ PDGF-AB (Peprotech, Rocky Hill, NJ) in invasion buffer (DMEM $+0.1 \%$ bovine serum albumin). After 24 hours of incubation in a $\mathrm{CO}_{2}$ incubator, Matrigel matrix and noninvading cells on the upper surface of the filter were removed by wiping with a cotton swab. The filters were then removed from the insert by a scalpel blade and mounted onto glass slides. The invading cells of each sample were counted in five randomly selected fields of duplicate filters under a microscope at $\times 200$ magnification. The invasive capacity of fibroblasts cultured in 10\% FBS DMEM alone (untreated/undifferentiated) was compared with fibroblasts cultured in $10 \mathrm{ng} / \mathrm{mL}$ TGF- $\beta$ or $50 \mu \mathrm{g} / \mathrm{mL}$ CpG-DNA, as indicated using the same invasion assay.

\section{In Vitro Cytotoxicity Assay}

Cells were cultured as indicated at $37^{\circ} \mathrm{C}$, and $10^{5}$ cells from each treatment were replated in 6-well plates for hypoxia studies. At the indicated times, cell cultures were subjected to the CellTiter Blue Assay, as per the manufacturer's instructions (Promega, San Luis Obispo, CA), and after 24 hours, fluorescence of resorufin was measured at 560/590 $\mathrm{nm}$ in a microplate reader. The data are presented as percentage of viable cells (ratio of fluorescence values from cells in hypoxia/cells in normoxia) from a minimum of two independent experiments with a minimum of two different NHLF lines. 
Preparation of RNA and cDNA from Primary Pulmonary Fibroblast Lines

After treatments as described above, TRIzol Reagent (Life Technologies) was added to each well, and total RNA was then prepared according to the manufacturer's instructions. Purified RNA was subjected to RNeasy Cleanup (Qiagen, Valencia, CA) and subsequently reverse-transcribed into cDNA using iScript Select cDNA Synthesis Kit (Bio-Rad).

\section{Real-Time TaqMan PCR Analysis}

Matrigel matrix and noninvading cells on the upper surface of the filter were removed by wiping with a cotton swab, the polycarbonate filters with the invaded cells or migrated cells were washed once with PBS, and RNA was isolated from the cells using the RNAqueous-4PCR kit (Ambion, Austin, TX). Reverse transcription was performed using the iScript Select cDNA Synthesis Kit (Bio-Rad). Human TLR9, $P D G F R A$, and MMP14 gene expression was analyzed by a quantitative real-time PCR procedure using an ABI PRISM 7500 Sequence Detection System (Applied Biosystems, Foster City, CA). Primers and probe used for all targets were purchased from Applied Biosystems. Gene expression was normalized to glyceraldehyde-3-phosphate dehydrogenase, and the fold increase over untreated cells (not subjected to the invasion assay) in target gene expression was calculated according to the following formula: $2-\mathrm{C}_{\mathrm{T}}$ with invasion/ $2-\mathrm{C}_{\mathrm{T}}$ without invasion. Values were calculated for replicates of three to five independent experiments.

\section{Immunofluorescence}

NHLFs $\left(2 \times 10^{4}\right.$ cells per well $)$ were added to 8 -well glass Labtek II (Nunc, Rochester, NY) tissue culture plates containing DMEM supplemented with 10\% FBS and 1\% penicillin/streptavidin and the indicated treatments for the specified experiment. Cells were fixed in ice-cold methanol, permeabilized with $0.1 \%$ Triton-X-100 in PBS, blocked for 1 hour in $2 \%$ bovine serum albumin/PBS, and stained overnight at $4{ }^{\circ} \mathrm{C}$ with anti- $\alpha$-SMA (Abcam) or rabbit IgG isotype control (Abcam). After repeated washes in PBS, NHLFs were incubated with Alexa-Fluor488-conjugated donkey anti-rabbit IgG for 1 hour at room temperature. Cells were washed again in PBS, mounted, and visualized using a fluorescent microscope at $\times 200$ magnification.

\section{Cytokine and Chemokine Enzyme-Linked Immunosorbent Assay Analysis}

IL-4, IL-6, IL-13, interferon $\gamma$ (IFN- $\gamma$ ), monocyte chemoattractant protein-1, PDGF-BB, tumor necrosis factor $\alpha$, and IFN- $\alpha$ were detected in $50-\mu \mathrm{L}$ samples of cell-free supernatants from indicated treatments using the multiplexed magnetic bead Bio-Plex Pro Assay enzyme-linked immunosorbent assay technique (Bio-Rad). Cytokine and chemokine levels in each sample were normalized to total protein present, as measured by the Lowry protein assay.

\section{MMP-14 Immunohistochemistry}

Archival formalin-fixed, paraffin-embedded tissue blocks representative of non-IPF (chronic obstructive pulmonary disease/emphysema) were identified through a search of the Co-Path computerized database of the Department of Pathology, in compliance with Stony Brook University Human Subjects Institutional Review Board-approved protocols at Stony Brook University Medical Center. IPF lung tissue sections diagnostic of fibrotic and nonfibrotic lung disease, resulting from lung biopsies, lobectomies, transplant procedures, and lung volume reduction surgeries were obtained from the Lung Tissue Research Consortium Tissue Core Laboratory, a resource program of the National Heart, Lung, and Blood Institute (Bethesda, MD). Tissues were fixed in neutral-buffered formalin, paraffin embedded, and divided into sections ( $5 \mu \mathrm{m}$ thick). After deparaffinization, antigen retrieval was performed in Tris buffer $[20 \mathrm{mmol} / \mathrm{L}(\mathrm{pH} 6.0)]$ at $120^{\circ} \mathrm{C}$ for 10 minutes in a decloaking chamber. Sections were incubated using rabbit monoclonal anti-MMP-14 (EP1264Y) primary antibody (ab51074; Abcam), diluted 1:200, followed by detection with an avidin-biotin-based system (Vectastain ABC, Vector Laboratories, Burlingame, CA) and development with 3,3'-diaminobenzidine. The (positive) control tissue used for optimization of MMP-14 staining was human breast carcinoma. After dilute hematoxylin counterstaining, sections were dehydrated and coverslipped for bright-field microscopy. Negative controls were performed by substituting Tris-buffered saline and Tween 20 buffer for the primary antibody. The staining was evaluated independently by two pathologists (J.D. and Kenneth Shroyer) experienced in the assessment of lung disease in non-IPF control cases and IPF lung tissue. Semiquantitative staining intensity of control $(n=3)$ and IPF ( $n=13$ ) lung tissue was performed by J.D., who is experienced in the assessment of lung disease and was blind to the origin of the samples. The tissue was graded as follows: 0 , no reaction; 1 , mild or weak staining; 2 , moderate staining; 3 , intense or strong staining; NA, not applicable due to absence of fibroblastic foci in the examined slide.

\section{Statistical Analysis}

All results are expressed as means \pm SEM or median, as appropriate. Data were analyzed by Student's $t$-test for twogroup comparisons, or the means between groups at different time points were compared by one- or two-way analysis of variance, as appropriate. Individual differences between experimental groups were further analyzed using the unpaired $t$-test with multiple-comparisons post test. $P<0.05$ was 

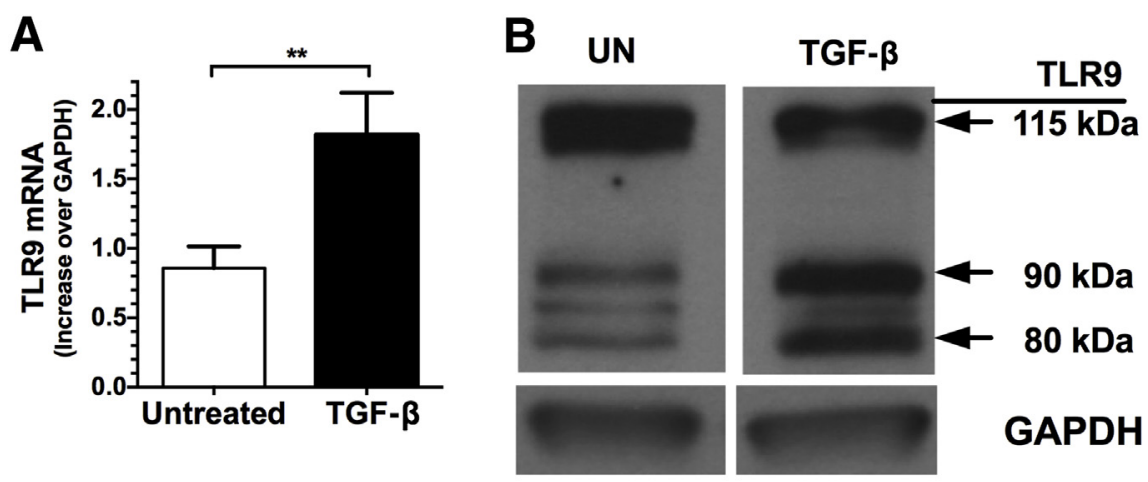

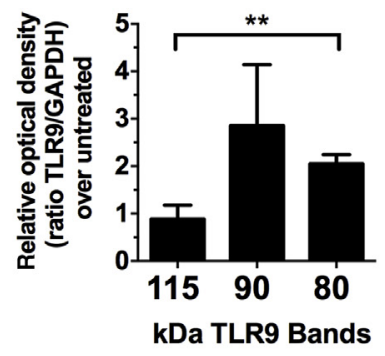

D

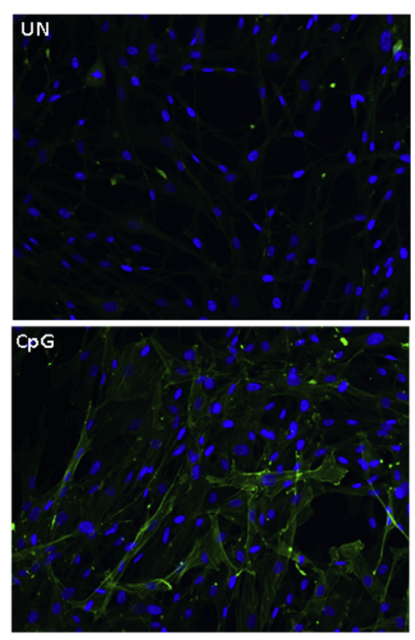

UN TGF- $\beta$ CpG
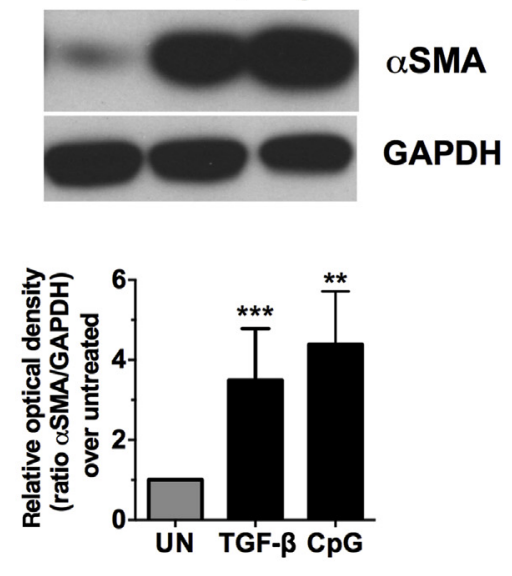

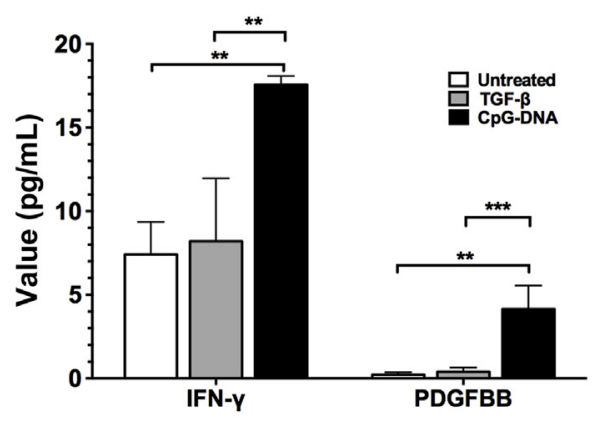

Figure 1 Toll-like receptor 9 (TLR9) induction by transforming growth factor (TGF)- $\beta$ and inflammatory cytokine secretion by TLR9-stimulated myofibroblasts. A: Real-time quantitative RT-PCR analysis of TLR9 gene expression in normal human lung fibroblasts (NHLFs) treated for 3 days without [untreated (UN)] or with TGF- $\beta$. B: Western blot analysis and quantitative densitometry of TLR9 protein and glyceraldehyde-3-phosphate dehydrogenase (GAPDH) reference protein in representative NHLFs cultured for 14 days without (UN) or with $10 \mathrm{ng} / \mathrm{mL}$ TGF- $\beta$. C: Fluorescent immunocytochemistry for DAPI (blue) and $\alpha$-smooth muscle actin ( $\alpha$-SMA; green) in NHLFs cultured without (UN) or with $50 \mu \mathrm{g} / \mathrm{mL} \mathrm{CpG-DNA.} \mathrm{Western} \mathrm{blot} \mathrm{analysis} \mathrm{and} \mathrm{quantitative} \mathrm{densitometry} \mathrm{of}$ $\alpha$-SMA protein and GAPDH reference protein in representative NHLF cell lines cultured for 14 days without (UN) or with $10 \mathrm{ng} / \mathrm{mL}$ TGF- $\beta$ or $50 \mu \mathrm{g} / \mathrm{mL}$ CpG-DNA. D: Bio-Plex analyses of conditioned media from NHLFs cultured for 14 days without (UN) or with $10 \mathrm{ng} / \mathrm{mL} \mathrm{TGF-} \beta$ or $50 \mu \mathrm{g} / \mathrm{mL}$ CpG-DNA for interferon $\gamma$ (IFN- $\gamma$ ) and platelet-derived growth factor-BB (PDGF-BB). Data are means \pm SEM. $n=5\left(\right.$ A) $; n=6$ (C and D); $n=8(\mathbf{B}) .{ }^{* * P}<0.01,{ }^{* * * P}<0.001 .0$ riginal magnification, $\times 40($ C).

considered significant and is indicated for each data set. GraphPad InStat statistical software version 6 (GraphPad Software, La Jolla, CA) was used for statistical analyses. Data are expressed as means and SEM for the number of studies performed.

\section{Results}

TGF- $\beta$ is the best-characterized profibrotic molecule, mediating numerous tissue repair processes, including proliferation and myofibroblastic differentiation of fibroblasts and epithelial-to-mesenchymal transition. ${ }^{2}$ TLR9, localized in the endolysosome, senses bacterial and viral DNA with unmethylated $\mathrm{CpG}$ motifs, which are major contributors to acute inflammation induced by an infection or, as until recently identified, self-mitochondrial DNA containing $\mathrm{CpG}$ motifs derived from compromised cells. ${ }^{17,28-31}$ Previous work has demonstrated that induction of TLR9 protein expression in lung fibroblasts from IPF patients, which originate from a TGF- $\beta$-rich environment, can be mediated by the profibrotic cytokines IL-4 and IL-13. ${ }^{32}$ However, the direct effect of TGF- $\beta$ on TLR9 expression has not been investigated. To test whether TGF- $\beta$-induced differentiation of fibroblasts results in altered levels of TLR9 levels compared to untreated fibroblasts, we evaluated TLR9 gene transcript and protein expression in primary NHLFs after prolonged stimulation with TGF- $\beta$ in vitro. This approach generated a uniform population of stably differentiated myofibroblasts, as previously described. ${ }^{33}$ We observed that TLR9 mRNA levels were significantly increased in NHLFs that have been cultured with TGF- $\beta$ for 3 to 14 days, compared to those cultured in growth medium alone (Figure 1A). In addition, an increase in the active lowermolecular-weight (80 to $90 \mathrm{kDa}$ ) forms of TLR9 was observed by immunoblotting (Figure 1B). These data demonstrated that TLR9 primarily exists as the full-length 
A
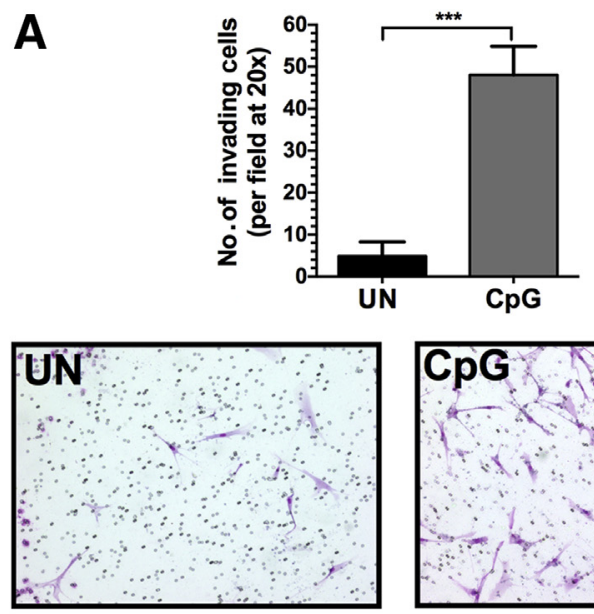

B
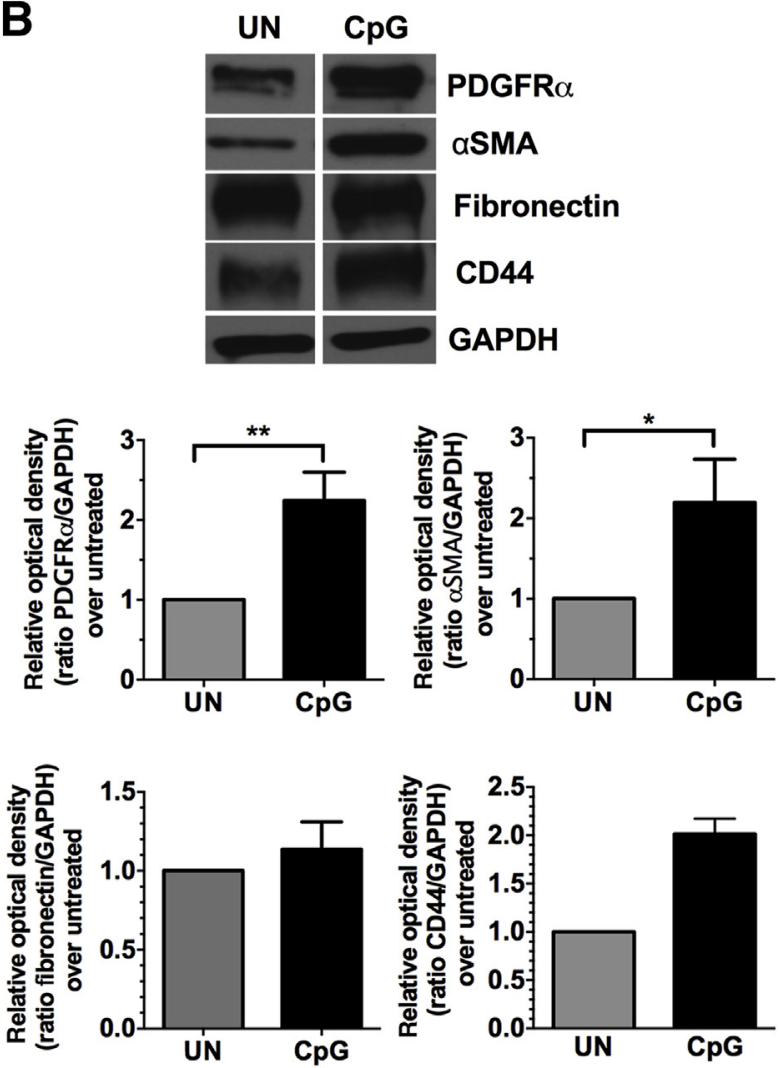

Figure 2 Invasive capacity of CpG-DNA-differentiated normal human lung fibroblasts (NHLFs) to platelet-derived growth factor-AB (PDGF-AB). A: The Matrigel-invading capacity toward PDGF-AB of NHLF cell lines cultured for 21 days without [untreated (UN)] or with $50 \mu \mathrm{g} / \mathrm{mL} \mathrm{CpG-DNA}$ was determined ( $n=$ 5 experiments). Data are shown as the number of cells per field detected on the filter with representative images of invasive NHLFs untreated or CpG-DNA treated for 3 weeks. B: Western blot analysis and quantitative densitometry of PDGF receptor $\alpha$ (PDGFR $\alpha), \alpha$-smooth muscle actin ( $\alpha$ SMA), fibronectin, CD44, and glyceraldehyde-3-phosphate dehydrogenase (GAPDH) using specific antibodies in lysates from UN or CpG-DNA-treated NHLFs for 3 weeks. $n=2($ A); $n=5$ (B). ${ }^{*} P<0.05,{ }^{*} P<0.01$, and ${ }^{* * *} P<0.001$. Original magnification, $\times 200$ (middle and right panels, $\mathrm{A}$ ).

inactive protein (approximately $115 \mathrm{kDa}$ ) in quiescent NHLFs, whereas TGF- $\beta$ stimulation induced an increase in both mRNA expression and in the active cleaved forms of TLR9. ${ }^{29}$ In contrast, protein levels of the other intracellular
TLRs (TLR3 and TLR7) were not altered by TGF- $\beta$ treatment (Supplemental Figure S1), suggesting a selective up-regulation of TLR9.

Previously, we reported that IPF fibroblasts, monocytes, and A549 epithelial cells treated with CpG-DNA, the primary ligand for TLR9, drive cells to differentiate into $\alpha \mathrm{SMA}^{+}$ myofibroblasts after 24 to 48 hours of stimulation in vitro. ${ }^{8,32}$ We next asked whether persistent TLR9 stimulation of primary NHLFs, which would be more physiologically representative, also produce $\alpha \mathrm{SMA}^{+}$myofibroblasts. Evaluation of cells cultured with prolonged CpG-DNA treatment in vitro (Figure $1 \mathrm{C}$ ) showed that $\alpha \mathrm{SMA}$ protein expression was clearly elevated in NHLFs cultured with either CpG-DNA or TGF- $\beta$ (positive control) versus the unstimulated sham-treated cells. NHLFs examined by immunofluorescence using anti$\alpha$ SMA antibody also show a distinct $\alpha \mathrm{SMA}^{+}$myofibroblast phenotype when cells were cultured with CpG-DNA (Figure 1C). The effect of CpG-DNA stimulation on the production of inflammatory and fibrotic cytokines by NHLFs was investigated next to further characterize the functional capacity of CpG-DNA-differentiated myofibroblasts. Cell-free culture supernatants from CpG-DNAtreated, TGF- $\beta$-treated, or sham-stimulated NHLFs were tested by multiplex enzyme-linked immunosorbent assay (BioPlex) to measure IL-4, IL-6, IL-13, IFN- $\alpha$, IFN- $\gamma$, monocyte chemoattractant protein-1 (chemokine ligand 2), PDGF-BB, and tumor necrosis factor $\alpha$. We observed significant differences in IFN- $\gamma$ and PDGF-BB production (Figure 1D) by CpG-DNA-differentiated NHLFs compared to untreated and TGF- $\beta$-differentiated NHLFs; all other cytokines tested did not show statistically significant differences. However, elevated levels of monocyte chemoattractant protein-1 and IFN- $\alpha$ in conditioned media of CpGDNA-differentiated myofibroblasts, compared to untreated and TGF- $\beta$-differentiated cells, were observed (Supplemental Figure S2). These data indicate that CpG-DNA-differentiated myofibroblasts have distinct inflammatory properties.

Unrelenting accumulation of aggressive myofibroblasts at sites of tissue remodeling is believed to ultimately compromise organ function and promote IPF progression. ${ }^{20,34}$ To further characterize the profibrotic function of CpG-DNAdifferentiated myofibroblasts, we next tested for their capacity to invade through Matrigel and then traverse an 8 - $\mu \mathrm{m}$ pore-size polycarbonate filter toward the potent profibrotic chemoattractant PDGF-AB. CpG-DNA-differentiated myofibroblasts demonstrated a significant increase in the number of invading cells compared to sham-treated cells (Figure 2A). CpG-DNA-differentiated NHLFs subjected to the PDGF invasion assay also express increased levels of PDGFR $\alpha, \mathrm{CD} 44$, and $\alpha \mathrm{SMA}$, (Figure 2B), molecules that have been linked to an invasive phenotype in myofibroblasts. ${ }^{20}$ To characterize the invading CpG-DNA-differentiated fibroblasts, we analyzed the expression of MMPs, which promote fibroblast migration and invasion. Supplemental Figure S3 shows that, although highly variable, MMP-9, MMP-12, and MMP-14 mRNAs were generally increased in the CpG-DNA-differentiated total 
A

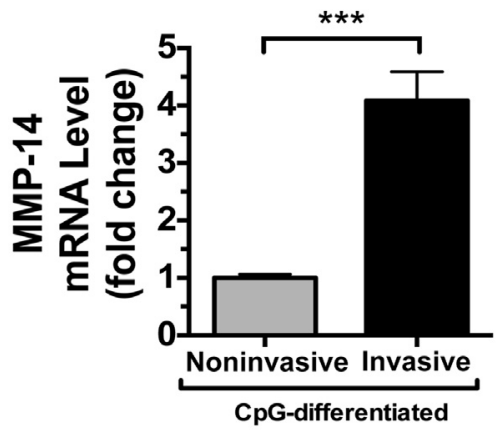

B



Figure 3 Matrix metalloproteinase (MMP) expression and activity in CpG-DNA-differentiated normal human lung fibroblasts (NHLFs). A: Relative MMP-14 mRNA expression from 3-week CpG-DNA-differentiated NHLFs in the polycarbonate filter fraction (invasive) after Matrigel invasion assay toward platelet-derived growth factor-AB (PDGF-AB) or in the total cell population (noninvasive population) ( $n=3$ experiments). B: Gelatin zymography for MMP activity and total protein detected by Coomassie Blue stain in lysates from NHLFs cultured for 14 days without [untreated (UN)] or with 2 or $10 \mathrm{ng} / \mathrm{mL}$ transforming growth factor (TGF) $\beta$ or $50 \mu \mathrm{g} / \mathrm{mL}$ CpG-DNA. Western blot analysis of MMP-14, MMP-2, and glyceraldehyde-3phosphate dehydrogenase (GAPDH) using specific antibodies in lysates from UN or treated with 2 or $10 \mathrm{ng} / \mathrm{mL}$ TGF- $\beta$ or $50 \mu \mathrm{g} / \mathrm{mL}$ CpG-DNA $(n=3) .{ }^{* *} P<0.001$.

fibroblast population compared to undifferentiated fibroblasts; however, only MMP-14 mRNA was significantly up-regulated in invading CpG-DNA-differentiated fibroblasts isolated from the filter (Figure 3A). The elevated MMP mRNA was reflected in increased levels of MMP activity detected by zymography in CpG-DNA-differentiated cells compared to undifferentiated and TGF- $\beta$-differentiated cells (Figure 3B). Furthermore, immunoblotting of cell lysates revealed that $\mathrm{CpG}-\mathrm{DNA}$-differentiated fibroblasts also have enhanced expression of MMP-14 protein (Figure 3B). MMP-14 enhances extracellular membrane remodeling and cell invasion by proteolytic activation of the proenzyme for MMP-2. ${ }^{35}$ Only the cleaved (activated) form of MMP-2 was detected in lysates from CpG-DNA-differentiated fibroblasts (Figure 3B), providing further evidence of enhanced MMP-14 activity that correlates with the invasive myofibroblast phenotype.

We next investigated how TGF- $\beta$-differentiated NHLFs respond to CpG-DNA stimulation. In both undifferentiated (no
TGF- $\beta$ ) and TGF- $\beta$-differentiated NHLFs, the protein levels of both MMP-14 and the PDGFR $\alpha$ were increased after CpGDNA stimulation (Figure 4A). Cleaved MMP-2 protein levels were increased in lysates of undifferentiated cells (no TGF- $\beta$ ) stimulated with CpG-DNA compared to control cells (untreated), but a more pronounced increase in cleaved MMP-2 was observed in $\alpha$-SMA ${ }^{+}$TGF- $\beta$-differentiated NHLFs stimulated with CpG-DNA (Figure 4A). Cytokine secretion from TGF- $\beta$-differentiated versus undifferentiated fibroblasts (no TGF- $\beta$ ), both stimulated with CpG-DNA, was evaluated next. The proinflammatory cytokine, IL-6, was increased in undifferentiated fibroblasts stimulated with CpGDNA (Figure 4B). In contrast, IL-6 levels were comparable between untreated, undifferentiated fibroblasts (negative control), TGF- $\beta$ alone, and TGF- $\beta$-differentiated NHLFs stimulated with CpG-DNA. Cells treated with CpG-DNA increased their level of IFN- $\gamma$ secretion regardless of whether they were undifferentiated or TGF- $\beta$ differentiated. To further examine the functional role of TLR9 in TGF- $\beta$-differentiated versus undifferentiated fibroblasts (no TGF- $\beta$ ), we tested their invasive capacity through Matrigel toward PDGF-AB in the presence of CpG-DNA stimulation with and without the TLR9 antagonist, chloroquine. Chloroquine prevents TLR9dependent CpG DNA cell activation by inhibiting endosomal acidification, a prerequisite for binding of $\mathrm{CpG}$ to the TLR9 ectodomain and consequent cellular activation. ${ }^{36-38}$ To further support data presented in Figure 4A, TGF$\beta$-differentiated NHLFs stimulated with CpG-DNA differentiated demonstrated a significant increase in the number of invading cells compared to sham-treated cells (Figure 4C). However, in the presence of chloroquine, this effect was inhibited. A statistically significant decrease in the number of invading cells was observed when chloroquine was added simultaneously to TGF- $\beta$-differentiated NHLFs stimulated with CpG-DNA. Collectively, these data provide further evidence that the cellular response to CpG-DNA in NHLFs is both dependent and independent of TGF- $\beta$ pathways.

Chronic inflammation in the lung induces fibroblast activation and proliferation along with interstitial thickening, and these changes can induce ventilation defects resulting in local tissue hypoxia. Chronic hypoxia is increasingly becoming a significant determinant of cancer and fibrosis in a variety of tissues. ${ }^{39,40}$ The unique property of cancer cells to thrive under hypoxic conditions has recently been attributed to their enhanced survival and drug resistance, ${ }^{40}$ and hypoxia has been shown to promote fibrogenesis by potentially initiating the development and progression of renal disease. ${ }^{41}$ These recent data all highlight the ability of aggressive cell phenotypes to survive and thrive under hypoxic conditions. Therefore, we next investigated the response of CpG-DNA-differentiated fibroblasts to hypoxia in this context. NHLFs were either cultured in medium alone (untreated) or differentiated for 3 weeks with TGF- $\beta$ or CpG-DNA; then, all cells were exposed to hypoxic or normoxic conditions for 24 hours. Figure 5A shows clear morphological differences and enhanced cell loss in untreated 
A
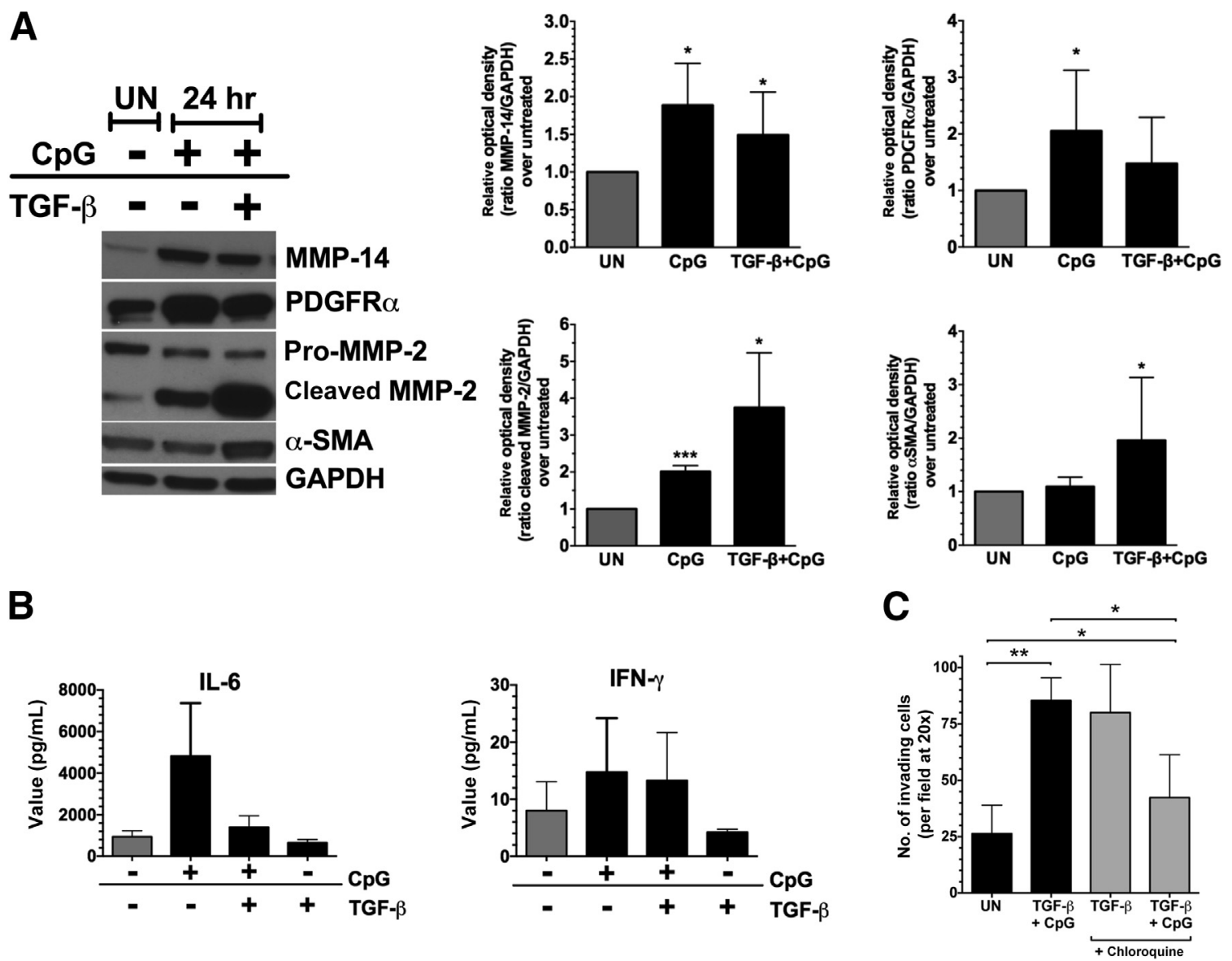

Figure 4 Transforming growth factor (TGF)- $\beta$-differentiated fibroblast response to CpG-DNA stimulation. A: Western blot analysis and quantitative densitometry of matrix metalloproteinase 14 (MMP-14), platelet-derived growth receptor factor $\alpha$ (PDGFR $\alpha$ ), MMP-2 (pro- and cleaved), $\alpha$-smooth muscle actin ( $\alpha$ SMA), and glyceraldehyde-3-phosphate dehydrogenase (GAPDH) using specific antibodies in lysates from cells untreated [UN (-/-)] or normal human lung fibroblasts (NHLFs) that have been differentiated with $10 \mathrm{ng} / \mathrm{mL}$ TGF- $\beta(+)$ for 2 weeks and then either sham or $50 \mu \mathrm{g} / \mathrm{mL}$ CpG-DNA treated (+) for an additional 24 hours. B: Bio-Plex analyses of IL- 6 and interferon (IFN)- $\gamma$ in conditioned media from NHLFs cultured for 14 days in media alone ( $-/-$ ) or TGF- $\beta$ $(+)$, and stimulated with or without CpG-DNA $(+)$ for an additional 24 hours. C: The Matrigel-invading capacity toward PDGF-AB of NHLF cell lines $(n=3)$ that have been differentiated with $10 \mathrm{ng} / \mathrm{mL}$ TGF- $\beta(+)$ for 2 weeks and then either sham or $50 \mu \mathrm{g} / \mathrm{mL}$ CpG-DNA treated (+ for an additional 24 hours in the presence or absence of $10 \mu \mathrm{g} / \mathrm{mL}$ chloroquine was determined). Data are shown as the number of cells per field detected on the filter at $20 \times$ objective. $n=3$ (C); $n=4(\mathbf{A}) ; n=6$ (B). ${ }^{*} P<0.05,{ }^{*} P P<0.01$, and ${ }^{* *} * P<0.001$.

and TGF- $\beta$-differentiated fibroblasts versus CpG-DNAdifferentiated cells when exposed to hypoxia. The viability of these fibroblasts after hypoxia was verified using the CellTiter Blue Viability Assay. Indeed, CpG-DNA-differentiated fibroblasts had enhanced survival under hypoxic conditions, supporting the morphological data (Figure 5B). Moreover, as assessed by the ability to metabolize CellTiter Blue, this assay revealed that CpG-DNA-differentiated fibroblasts exposed to hypoxia were as viable as those cells maintained in normoxia (Figure 5B).

Hypoxia-inducible factors (HIFs) are a family of transcription factors that function as major regulators of hypoxic signaling and cause increased cell apoptosis. HIF- $1 \alpha$ and HIF- $2 \alpha$ have been shown to activate common target genes via the hypoxia-responsive-element site, including those implicated in the pathogenesis of IPF, such as vascular endothelial growth factor, endothelin-1, and C-X-C chemokine receptor $4 .^{42-44}$ Under normoxia, HIF-1 $\alpha$ becomes hydroxylated at proline residues and is degraded in the proteasome; under hypoxia, HIF- $1 \alpha$ is stabilized and translocates to the nucleus to induce transcription of target genes. Recently, HIF- $2 \alpha$ (but not HIF-1 $\alpha$ ) has been shown to promote tumor growth and vascular tumorigenesis in mouse models of renal carcinoma and liver hemangiomas, suggesting that it plays a critical role in cancer. ${ }^{45-48}$ HIF- $1 \alpha$ and HIF- $2 \alpha$ protein expression was evaluated by immunoblotting in CpG-DNA-differentiated fibroblasts exposed to hypoxia. HIF- $1 \alpha$ is induced in both undifferentiated and CpGDNA-differentiated fibroblasts after hypoxia (Figure 5C). In contrast, HIF- $2 \alpha$ is depressed in CpG-DNA-differentiated fibroblasts compared to undifferentiated cells exposed to hypoxia (Figure 5C), further demonstrating that CpG-DNAdifferentiated fibroblasts are unresponsive to deleterious effects of hypoxia. We did not observe induction of either HIF- $1 \alpha$ or HIF- $2 \alpha$ protein expression under normoxia conditions (Supplemental Figure S4). Because hypoxia results in 


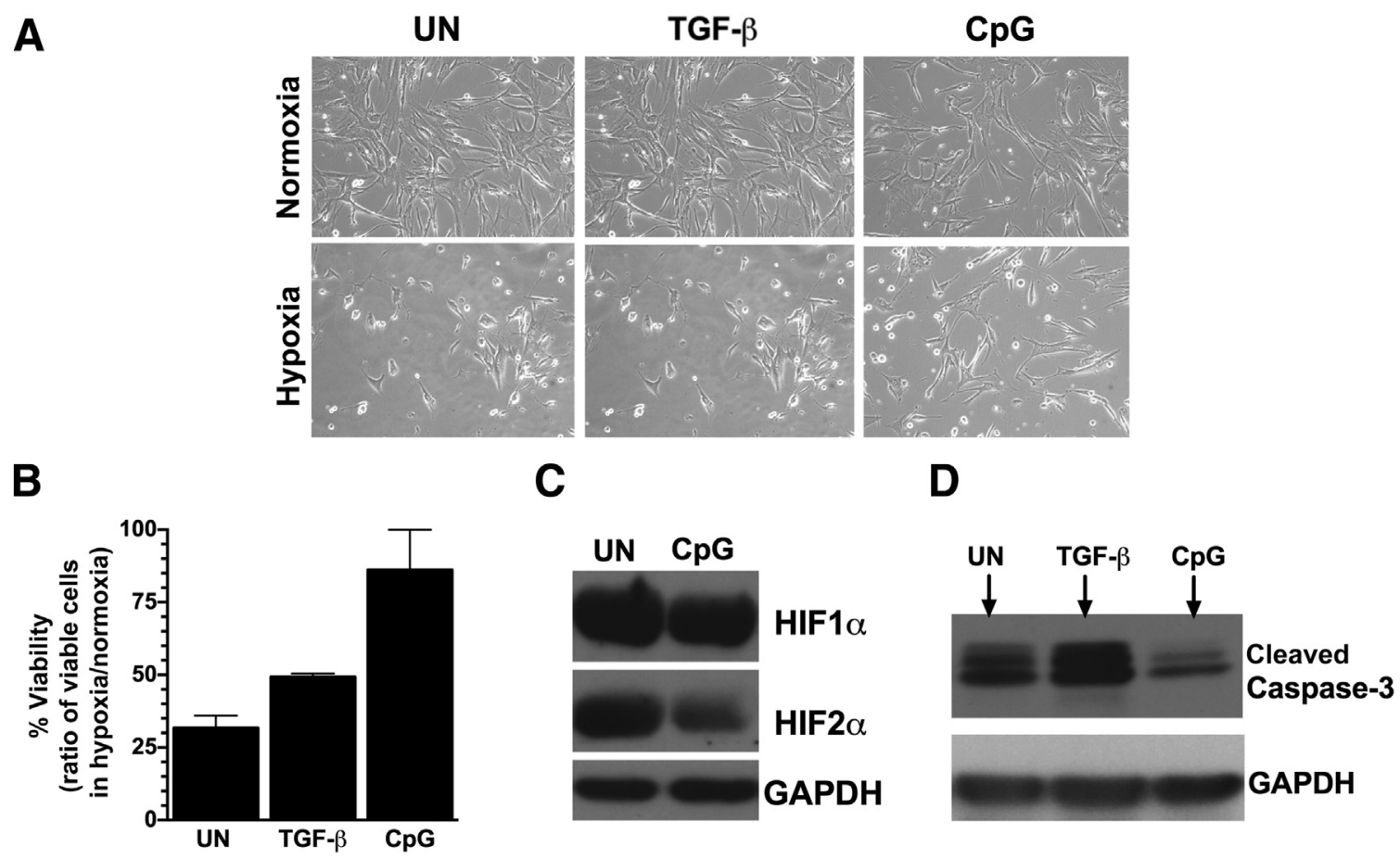

Figure 5 Hypoxia-induced apoptosis in CpG-DNA-differentiated fibroblasts. A: Representative phase-contrast photomicrographs of normal human lung fibroblast (NHLF) cell lines $(n=4)$ cultured without [untreated (UN)] or with $10 \mathrm{ng} / \mathrm{mL}$ transforming growth factor (TGF)- $\beta$ or $50 \mu \mathrm{g} / \mathrm{mL}$ CpG-DNA for 3 weeks and then subjected to normoxic or hypoxic conditions $\left(5 \% \mathrm{O}_{2}\right)$ for an additional 24 hours. B: Representative data from four separate experiments showing resorufin production measured in cell-free supernatants from cells after normoxic/hypoxic conditions using the CellTiter Blue Cell Viability Assay, presented as percentage of viable cells (ratio of fluorescence values from cells in hypoxia/cells in normoxia). Data are shown from two independent experiments with two different NHLF lines. Representative Western blot analysis of hypoxia-inducible factor (HIF) $1 \alpha$, HIF2 $\alpha$, and glyceraldehyde-3-phosphate dehydrogenase $($ GAPDH ; C) and cleaved caspase-3 (D) using specific antibodies in lysates from UN, or with $10 \mathrm{ng} / \mathrm{mL} \mathrm{TGF-} \beta$ - or $50 \mu \mathrm{g} / \mathrm{mL}$ CpG-DNA-treated NHLFs for 3 weeks and exposed to hypoxia for 24 hours.

activation of caspase- 3 and subsequent apoptosis, ${ }^{49,50}$ we next examined caspase-3 in NHLFs exposed to hypoxia. CpGDNA-differentiated fibroblasts, as compared to untreated and TGF- $\beta$-differentiated fibroblasts, demonstrated reduced caspase-3 cleavage by immunoblot analysis (Figure 5D). Collectively, these data indicate that CpG-DNA-differentiated fibroblasts are resistant to hypoxia-induced apoptosis mediated by caspase- 3 .

The data presented above demonstrate that TLR9stimulated normal lung fibroblasts acquire a profibrotic phenotype and increased MMP-14. We next compared MMP14 expression by immunofluorescence in fibroblasts cultured from IPF lungs to untreated NHLFs. MMP-14 protein is detectable in all observed IPF fibroblasts compared to scant expression by NHLFs (Figure 6A). MMP-14 has been previously found to be up-regulated in IPF, increased in nearly all human cancers when compared to normal tissue, elevated in patients with metastasis, and correlated with reduced survival. ${ }^{51-54}$ Expression of MMP-14 mRNA was significantly increased in IPF lung tissue compared to non-IPF control cases (nonfibrotic) lung tissue (Figure 6B). In agreement with previously published data, ${ }^{54}$ semiquantitative analysis of MMP-14 in non-IPF control cases versus IPF lung tissue (Table 1) showed MMP-14 protein expression in multiple cell types, with moderate to strong staining intensities observed in myofibroblasts and epithelial cells associated with fibroblast foci of IPF cases (Figure 6C and Supplemental Figure S5). Non-IPF control cases, which lacked fibroblast foci, showed only weak to, at most, moderate staining in interstitial fibroblasts/myofibroblasts. These data further support previously published data that propose MMP-14 to be a potential marker of a profibrotic myofibroblast phenotype in IPF. ${ }^{55}$

\section{Discussion}

Previously, we defined a clinical subset of patients with rapid deterioration of lung function and a significantly increased mortality rate (rapid progressors). ${ }^{8}$ We further identified the innate immune receptor TLR9 as strongly associated with this aggressive variant of IPF and demonstrated enhanced TLR9 expression on myofibroblasts ${ }^{8,32}$; however, it is not known how TLR9 becomes overexpressed and deregulated in rapid IPF, and why TLR $9^{\mathrm{Hi}}$ patients exhibit a rapid decline. ${ }^{7,56}$ Herein, we have extended those observations and present new information on the regulation of TLR9 expression in human lung fibroblasts and the functional characteristics these cells acquire in response to persistent TLR9 stimulation with CpG-DNA. We believe that these results will provide a better understanding of the 

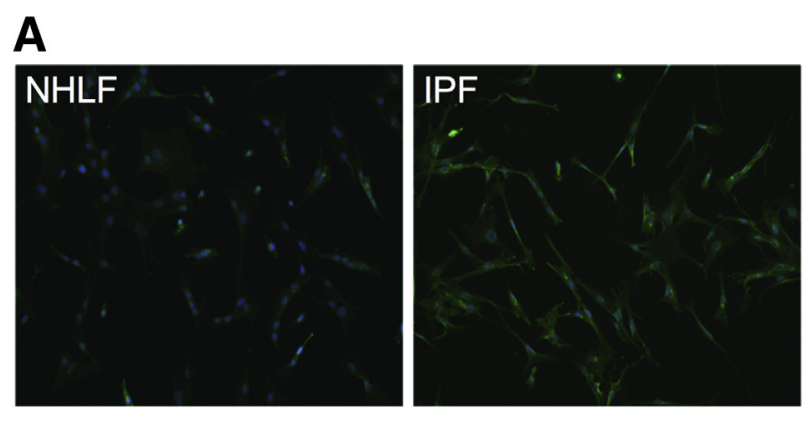

B

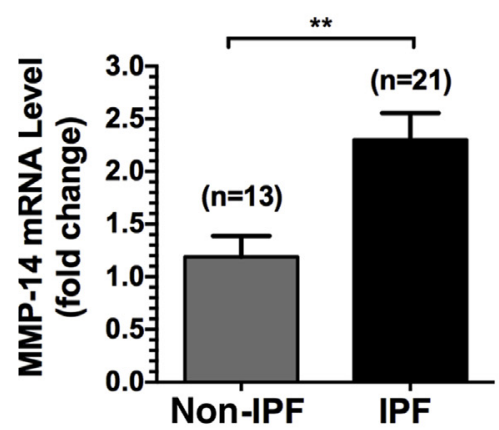

C
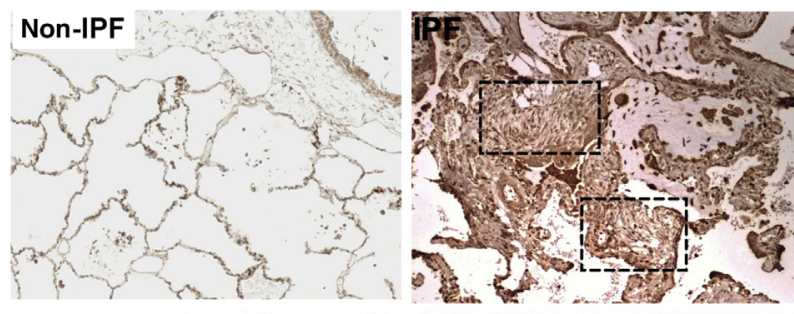

Non-IPF

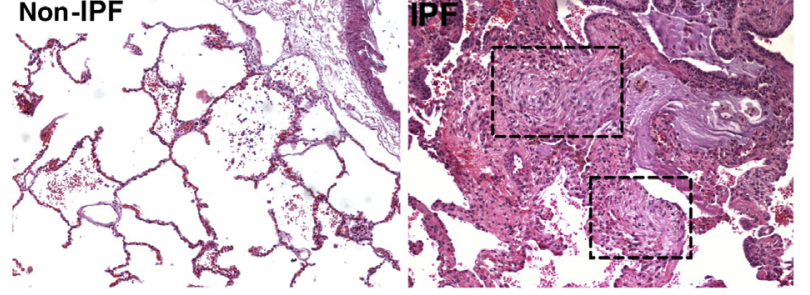

Figure 6 Matrix metalloproteinase 14 (MMP-14) in idiopathic pulmonary fibrosis (IPF) lung fibroblasts and tissue biopsy specimens. A: Fluorescent immunocytochemistry for DAPI (blue) and MMP-14 (green) in normal human lung fibroblasts and IPF lung fibroblasts. B: Relative MMP-14 mRNA expression in non-IPF and IPF lung tissue. C: Representative MMP-14 immunohistochemistry on non-IPF controls and IPF lung tissue (top panels). Adjacent sections were stained with hematoxylin and eosin (bottom panels). Black dotted boxes for the IPF cases highlight fibroblastic foci. ${ }^{* *} P<0.01$. Original magnifications: $\times 40$ (A); $\times 60$ (C).

pathogenesis of IPF, particularly the rapidly progressive form of the disease. In the IPF lung, activated myofibroblasts persist and nourish the fibrotic process by depositing extracellular matrix. In addition, they are also capable of producing large amounts of MMPs that facilitate the destruction of the alveolar basement membrane, allowing the penetration of these cells into alveolar spaces. In this way, infiltrating myofibroblasts form cell aggregates (fibroblastic foci) that are a histological hallmark of active pulmonary fibrosis. ${ }^{19}$ Several studies have demonstrated that IPF lung fibroblasts acquire an invasive phenotype that is mediated by distinct pathways. ${ }^{20,57,58}$ The data presented herein support this model of activated myofibroblast invasion as a potential mechanism for rapid progression of IPF. Repeated stimulation of NHLFs with the TLR9 ligand CpG-DNA generates active myofibroblasts with up-regulated $\alpha$-SMA expression, similar to TGF- $\beta$-treated fibroblasts. In contrast, TLR9-stimulated myofibroblasts show a distinct expression pattern of proinflammatory cytokines compared to TGF- $\beta$-differentiated NHLFs, indicating that different pathways are capable of inducing signals to maintain a chronic inflammatory environment conducive for fibrogenesis. Therefore, identifying the mechanisms that generate and maintain myofibroblasts in their active state is important for understanding the components of the rapidly progressive clinical phenotype of IPF.

A salient feature of the CpG-DNA-differentiated myofibroblasts reported herein was their ability to invade extracellular matrix toward a PDGF gradient and their overexpression of PDGFR $\alpha$, MMP-14 (MT1-MMP), and active MMP-2. MMPs have been strongly implicated in several interrelated processes observed in the pathogenesis of pulmonary fibrosis, including extracellular membrane remodeling, basement membrane breakdown, epithelial cell apoptosis, and migration. ${ }^{59}$ Both membrane-associated MMP-14 and its soluble zymogen substrate, MMP-2, previously have been found to be strongly up-regulated in IPF lung tissue. ${ }^{31,32}$ In addition, increased levels of active MMP-2 were reported in bronchoalveolar lavage fluids from IPF patients. ${ }^{54}$ Likewise, we detected markedly increased expression of MMP-14 protein in IPF lungs, in contrast to normal and non-IPF lung tissue. The long-term myofibroblast differentiation studies with $\mathrm{CpG}$ DNA, combined with a short-term stimulation of TGF$\beta$-differentiated myofibroblasts (Figure 4), demonstrate that expression of MMP-14 (and subsequent activation of MMP-2) is downstream of TLR9 activation. These data are consistent with a proposed mechanism whereby TLR9 mediates the expansion of activated myofibroblasts and fibrogenesis through a pathway linked to MMP-14 and MMP-2.

Interestingly, this is not the first report describing a mechanism by which TLR9 may enhance cellular invasiveness through MMP activation. A previous study demonstrated that treatment of breast cancer cells with $\mathrm{CpG}$ oligonucleotides directly increased MMP activity via a TLR9dependent mechanism. ${ }^{60}$ Moreover, $\mathrm{CpG}$ oligonucleotide stimulation of TLR9 also has been shown to induce macrophage MMP-9 expression by activating extracellular signal-regulated kinase and $\mathrm{p} 38$ mitogen-activated protein kinase ${ }^{61}$ Stimulation of TLR9 with $\mathrm{CpG}$ oligonucleotides in both breast and prostate cancer cells dramatically increases the in vitro invasive capacity through Matrigel. ${ }^{60,62,63}$ Recent quantitative microarray gene expression analysis from our laboratory indicates that osteopontin is dramatically up-regulated (44-fold) in CpG-DNA-differentiated myofibroblast compared to TGF- $\beta$-differentiated cells 
TLR9 Promotes Invasive Myofibroblasts

Table 1 MMP-14 Immunoreactivity in Control and IPF Lung Cases

\begin{tabular}{|c|c|c|c|c|c|c|c|c|c|c|c|c|c|c|c|c|}
\hline \multirow[b]{2}{*}{ Site } & \multicolumn{3}{|c|}{$\begin{array}{l}\text { Non-IPF control } \\
\text { cases }\end{array}$} & \multicolumn{13}{|c|}{ IPF cases } \\
\hline & 1 & 2 & 3 & 4 & 5 & 6 & 7 & 8 & 9 & 10 & 11 & 12 & 13 & 14 & 15 & 16 \\
\hline Bronchiolar epithelial cells & 3 & 2 & 3 & 2 & 2 & 2 & 2 & 3 & 3 & 3 & 2 & 2 & 2 & 2 & 2 & 2 \\
\hline Alveolar epithelial cells (pneumocytes) & 2 & 3 & 2 & 2 & 2 & 2 & 2 & 3 & 3 & 3 & 2 & 2 & 2 & 3 & 2 & 3 \\
\hline Endothelial cells & 1 & 2 & 2 & 1 & 2 & 2 & 1 & 3 & 2 & 2 & 1 & 1 & 2 & 1 & 2 & 2 \\
\hline Epithelial cells lining fibroblast foci & NA & NA & NA & 2 & NA & 3 & 2 & 3 & 3 & NA & NA & 3 & NA & NA & 2 & NA \\
\hline Myofibroblasts in fibroblast foci & NA & NA & NA & 2 & NA & 2 & 2 & 3 & 3 & NA & NA & 2 & NA & NA & 2 & NA \\
\hline
\end{tabular}

The intensity of the immunohistochemical staining was graded as follows: 0 , no reaction; 1 , mild or weak staining; 2 , moderate staining; 3 , intense or strong staining; NA, not applicable due to absence of fibroblast foci in examined slide.

IPF, idiopathic pulmonary fibrosis; MMP, matrix metalloproteinase.

(V. Kirillov and G. Trujillo, unpublished data). Osteopontin (alias secreted phosphoprotein 1) is a cytokine that binds to the integrin family of adhesion molecules and is highly implicated in malignant transformation, metastasis, and IPF. ${ }^{64-68}$ Primary human lung fibroblasts and IPF epithelial cells both demonstrate a direct regulatory interaction between osteopontin and MMPs.

Elimination of myofibroblasts by apoptosis is essential during normal wound healing and is a major process that may be stalled or altered in fibrotic disorders. ${ }^{69}$ Deficient apoptosis and/or increased survival of myofibroblasts in human IPF represents a central mechanism for the development of fibroblastic foci. The ability of CpG-DNA-differentiated myofibroblasts to respond to apoptotic stimuli was tested by culturing them under conditions of hypoxia $\left(5 \% \mathrm{O}_{2}\right)$. Oxygen levels in lung tissue are difficult to quantify, but a role for hypoxia in the progression of pulmonary fibrosis has been supported by the observation that there is increased stabilization of HIF- $1 \alpha$ in human IPF lung tissue, as well as in mice with bleomycin-induced pulmonary fibrosis. ${ }^{70,71}$ Although a great deal is known about the role of transcription factors such as HIF- $1 \alpha$ in adaptive responses to acute hypoxia, the mechanisms that regulate transcriptional events in response to chronic hypoxia are less well understood. In IPF, HIF-1 $\alpha$ is absent in fibroblastic foci, whereas the anti-apoptotic protein Bcl-2 is increasingly expressed, supporting the hypothesis of increased alveolar epithelial cell apoptosis concomitantly with decreased fibroblast apoptosis. ${ }^{70} \mathrm{We}$ found that CpG-DNA-differentiated myofibroblasts are resistant to hypoxia-induced apoptosis compared to their TGF- $\beta$-differentiated counterparts. In addition, CpGDNA-differentiated myofibroblasts have decreased levels of HIF- $2 \alpha$, which is predominantly expressed in the lung and heart vasculature, in contrast to the ubiquitously expressed HIF- $1 \alpha{ }^{43}$ Thus, TLR9-activated myofibroblasts may contribute to disease progression in IPF because their normal apoptotic mechanisms are altered by hypoxia. However, this pathway of TLR9-mediated myofibroblast activation will require further investigation.
The dominant role of TGF- $\beta$ in myofibroblast differentiation and activation is well described in IPF, but its effect on fibroblast TLR9 regulation has not been investigated. Several studies recently have demonstrated that TLR9 activation requires proteolytic cleavage of its C-terminal ectodomain to recruit the signaling adaptor molecule, MyD88. TLR9 activation by proteolytic processing can be detected by the presence of lower-molecular-weight cleavage products on SDS-PAGE, ${ }^{72,73}$ a process mediated by cathepsins. ${ }^{73,74}$ We report that TLR9 in quiescent, undifferentiated fibroblasts primarily is found as the full-length (approximately $120 \mathrm{kDa}$ ) protein, in contrast to TGF$\beta$-differentiated myofibroblasts, where lower-molecularweight active forms of TLR9 become increasingly prominent with steady exposure to TGF- $\beta$ (Figure 1B). Moreover, we have recently identified increased expression of cathepsins in CpG-DNA-differentiated myofibroblasts, IPF fibroblasts, and IPF whole lung tissue (V. Kirillov and G. Trujillo, unpublished data), suggesting the possibility that alterations in cathepsin regulation may be a component of our proposed model for rapid progression. These studies are currently underway in our laboratory. Moreover, myofibroblasts are a significant source of TGF- $\beta$ that, in an autocrine manner, further stimulates myofibroblasts to maintain the phenotype. We propose that sustained TGF- $\beta$ stimulation also drives constitutive activation of TLR9. Normally, TLR9 is restricted to the endolysosomal compartment, and this is thought to limit TLR9 activation and prevent a response to self-nucleic acids. ${ }^{72}$ However, dysregulated TLR9 signaling in a fibrotic environment may be a potential mechanism by which TLR9 contributes to rapidly progressive IPF.

A major unresolved question is how does TLR9 play a pathogenic role in IPF patients with rapidly progressive disease, where evidence of active lung infections is often inconclusive. ${ }^{4,5}$ Numerous studies have increasingly demonstrated that TLRs also recognize self-epitopes that are either released from necrotic cells or present at the surface of apoptotic cells. In this context, TLR9 may play a critical 
role in tissue repair and the clearance of cellular debris in the fibrotic lung. ${ }^{7}$ However, failure to appropriately regulate self-responses triggered by certain TLRs can have serious pathological consequences. Although TLR9 was originally thought to specifically recognize microbial unmethylated CpG-rich DNA, and distinguish pathogen DNA from that of the host, it is now evident that mammalian DNA can be an efficient TLR9 ligand. ${ }^{75}$ Furthermore, other studies revealed specific instances in which mammalian DNA proved to be a highly effective TLR9 stimulus and point to a critical role for host DNA in the pathogenesis of certain autoimmune diseases. ${ }^{76-78}$ Collectively, our results reveal a phenotypic difference between TGF- $\beta$ - and CpG-DNA-differentiated NHLFs that may account for the increased presence of TLR9 ${ }^{+}$ myofibroblasts observed in IPF lung tissue. Accordingly, it will be important to understand how different forms of cell death (necrotic versus apoptotic) within the IPF lung microenvironment may contribute to the release of self CpG-rich DNA, leading to an exacerbation of the disease.

Recently, the concept that IPF is an uncontrolled proliferative disease similar to cancer has been discussed. ${ }^{19,21,79}$ Epigenetic and genetic abnormalities, altered cell-to-cell communications, uncontrolled proliferation, and abnormal activation of specific signal transduction pathways are hallmarks that characterize both IPF and cancer. ${ }^{19,56} \mathrm{Cu}$ mulative evidence suggests that IPF myofibroblasts may acquire properties similar to metastatic cancer cells, such as invasiveness and repressed apoptotic pathways, and TGF- $\beta$ is central to the pathways that produce this phenotype. ${ }^{19}$ Our recent data demonstrate that induction of a similar invasive fibroblast phenotype is mediated by augmented TLR9 activation. The data presented herein may also suggest that repeated exposure of profibrotic cytokines, such as TGF- $\beta$ and danger-associated molecular patterns (eg, CpG DNA), which may derive from an infectious source or mitochondrial DNA from damaged cells, may result in epigenetic changes that affect TLR9 responses. This hypothesis is supported by preliminary data in which CpG-differentiated myofibroblasts maintain their invasive phenotype up to 2 weeks after the CpG DNA stimulus is removed. Epigenetic information is encoded by differential methylation of DNA on cytosines and by proteins associating with DNA, such as histones, which may be modified covalently by acetylation, methylation, phosphorylation, and/or ubiquitination. Because this epigenetic information is heritable beyond cell division, the importance of epigenetic regulation is established, especially in the fields of developmental and cancer biology. ${ }^{80}$ In the context of epigenetic regulation of TLRs, TLR4 gene expression in intestinal epithelial cells has been identified as one mechanism for maintaining intestinal homeostasis by suppressing excessive inflammatory responses. New knowledge gained from the study of epigenetic regulation of TLRs may help to reveal why fibrotic cells, although similar in some respects to cancer cells, have a distinct function.
In summary, the current study demonstrates that TGF- $\beta$, the potent profibrotic cytokine fundamental in IPF development, maintains increased fibroblast levels of TLR9 in the active cleaved form. We show that TGF- $\beta$-induced TLR $9^{\mathrm{Hi}}$ myofibroblasts phenotypically are $\alpha-\mathrm{SMA}^{+} / \mathrm{MMP}-14^{+} / \mathrm{MMP}^{-} 2^{+} /$ PDGFR- $\alpha^{+}$, hyperresponsive to CpG-DNA, proinflammatory, invasive, and hypoxia resistant. Although the mechanism of TGF- $\beta$-mediated TLR9 up-regulation is not known, our data inspire several areas of investigation in rapidly progressive IPF. Although TLR9 binds unmethylated CpG sequences in bacte$\mathrm{rial} / \mathrm{viral}$ DNA, an infectious source of CpG-DNA has not been identified in rapidly progressive IPF patients. Therefore, we are currently investigating sterile inflammatory injury because TLR9 also is activated by mitochondrial DNA. In this model, we propose that this process would trigger enhanced and sustained TLR9 signaling, generating a positive feedback loop that generates more TLR9 ${ }^{\mathrm{Hi}}$ myofibroblasts, resulting in rapid acceleration of IPF. These studies currently underway in our laboratory may reveal a novel mechanism by which TGF- $\beta$ promotes myofibroblast expansion in rapid IPF and may identify new pathways to therapeutically target in this devastating disease.

\section{Acknowledgments}

We thank Purvi Patel (Stony Brook University, Stony Brook, NY) for technical support, Dr. Jian Cao (Stony Brook University) for helpful discussions and technical advice surrounding the MMP-14 and -2 studies, Dr. Richard Kew (Stony Brook University) for reviewing and editing the manuscript, the Research Histology Core Laboratory and Dr. Kenneth Shroyer (Stony Brook Medicine) for providing valuable technical support and interpretation of immunohistochemical analysis, and the Lung Tissue Research Consortium for kindly providing the idiopathic pulmonary fibrosis and control lung tissue.

\section{Supplemental Data}

Supplemental material for this article can be found at http://dx.doi.org/10.1016/j.ajpath.2014.12.011.

\section{References}

1. Blackwell TS, Tager AM, Borok Z, Moore BB, Schwartz DA Anstrom KJ, et al: Future directions in idiopathic pulmonary fibrosis research: an NHLBI workshop report. Am J Respir Crit Care Med 2014, 189:214-222

2. Fernandez IE, Eickelberg O: The impact of TGF-beta on lung fibrosis: from targeting to biomarkers. Proc Am Thorac Soc 2012, 9: $111-116$

3. Moore B, Lawson WE, Oury TD, Sisson TH, Raghavendran K, Hogaboam CM: Animal models of fibrotic lung disease. Am J Respir Cell Mol Biol 2013, 49:167-179

4. Wootton SC, Kim DS, Kondoh Y, Chen E, Lee JS, Song JW, Huh JW, Taniguchi H, Chiu C, Boushey H, Lancaster LH, Wolters PJ, DeRisi J, Ganem D, Collard HR: Viral infection in acute 
exacerbation of idiopathic pulmonary fibrosis. Am J Respir Crit Care Med 2011, 183:1698-1702

5. Collard HR, Moore BB, Flaherty KR, Brown KK, Kaner RJ, King TE Jr, Lasky JA, Loyd JE, Noth I, Olman MA, Raghu G, Roman J, Ryu JH, Zisman DA, Hunninghake GW, Colby TV, Egan JJ, Hansell DM, Johkoh T, Kaminski N, Kim DS, Kondoh Y, Lynch DA, Muller-Quernheim J, Myers JL, Nicholson AG, Selman M, Toews GB, Wells AU, Martinez FJ: Acute exacerbations of idiopathic pulmonary fibrosis. Am J Respir Crit Care Med 2007, 176:636-643

6. Selman M, Carrillo G, Estrada A, Mejia M, Becerril C, Cisneros J, Gaxiola M, Perez-Padilla R, Navarro C, Richards T, Dauber J, King TE Jr, Pardo A, Kaminski N: Accelerated variant of idiopathic pulmonary fibrosis: clinical behavior and gene expression pattern. PLoS One 2007, 2:e482

7. Hogaboam CM, Trujillo G, Martinez FJ: Aberrant innate immune sensing leads to the rapid progression of idiopathic pulmonary fibrosis. Fibrogenesis Tissue Repair 2012, 5(Suppl 1):S3

8. Trujillo G, Meneghin A, Flaherty KR, Sholl LM, Myers JL, Kazerooni EA, Gross BH, Oak SR, Coelho AL, Evanoff H, Day E, Toews GB, Joshi AD, Schaller MA, Waters B, Jarai G, Westwick J, Kunkel SL, Martinez FJ, Hogaboam CM: TLR9 differentiates rapidly from slowly progressing forms of idiopathic pulmonary fibrosis. Sci Transl Med 2010, 2:57ra82

9. Holm CK, Paludan SR, Fitzgerald KA: DNA recognition in immunity and disease. Curr Opin Immunol 2013, 25:13-18

10. Stewart JP, Egan JJ, Ross AJ, Kelly BG, Lok SS, Hasleton PS, Woodcock AA: The detection of Epstein-Barr virus DNA in lung tissue from patients with idiopathic pulmonary fibrosis. Am J Respir Crit Care Med 1999, 159:1336-1341

11. Tang YW, Johnson JE, Browning PJ, Cruz-Gervis RA, Davis A, Graham BS, Brigham KL, Oates JA Jr, Loyd JE, Stecenko AA: Herpesvirus DNA is consistently detected in lungs of patients with idiopathic pulmonary fibrosis. J Clin Microbiol 2003, 41: $2633-2640$

12. Calabrese F, Kipar A, Lunardi F, Balestro E, Perissinotto E, Rossi E, Nannini N, Marulli G, Stewart JP, Rea F: Herpes virus infection is associated with vascular remodeling and pulmonary hypertension in idiopathic pulmonary fibrosis. PLoS One 2013, 8: e55715

13. Guggemoos S, Hangel D, Hamm S, Heit A, Bauer S, Adler H: TLR9 contributes to antiviral immunity during gammaherpesvirus infection. J Immunol 2008, 180:438-443

14. Zauner L, Nadal D: Understanding TLR9 action in Epstein-Barr virus infection. Front Biosci (Landmark Ed) 2012, 17:1219-1231

15. Folcik VA, Garofalo M, Coleman J, Donegan JJ, Rabbani E, Suster S, Nuovo A, Magro CM, Di Leva G, Nuovo GJ: Idiopathic pulmonary fibrosis is strongly associated with productive infection by herpesvirus saimiri. Mod Pathol 2014, 27:851-862

16. Wynn TA: Cellular and molecular mechanisms of fibrosis. J Pathol 2008, 214:199-210

17. Ellson CD, Dunmore R, Hogaboam CM, Sleeman MA, Murray LA: Danger-associated molecular patterns and danger signals in IPF. Am J Respir Cell Mol Biol 2014, 51:163-168

18. Droemann D, Albrecht D, Gerdes J, Ulmer AJ, Branscheid D, Vollmer E, Dalhoff K, Zabel P, Goldmann T: Human lung cancer cells express functionally active Toll-like receptor 9. Respir Res 2005, 6:1

19. Vancheri C: Common pathways in idiopathic pulmonary fibrosis and cancer. Eur Respir Rev 2013, 22:265-272

20. Li Y, Jiang D, Liang J, Meltzer EB, Gray A, Miura R, Wogensen L, Yamaguchi Y, Noble PW: Severe lung fibrosis requires an invasive fibroblast phenotype regulated by hyaluronan and CD44. J Exp Med 2011, 208:1459-1471

21. Vancheri C: Idiopathic pulmonary fibrosis: an altered fibroblast proliferation linked to cancer biology. Proc Am Thorac Soc 2012, 9: $153-157$
22. Bruce MC, Honaker CE: Transcriptional regulation of tropoelastin expression in rat lung fibroblasts: changes with age and hyperoxia. Am J Physiol 1998, 274:L940-L950

23. Wang J, Chen H, Seth A, McCulloch CA: Mechanical force regulation of myofibroblast differentiation in cardiac fibroblasts. Am J Physiol Heart Circ Physiol 2003, 285:H1871-H1881

24. Chailley-Heu B, Boucherat O, Barlier-Mur AM, Bourbon JR: FGF18 is upregulated in the postnatal rat lung and enhances elastogenesis in myofibroblasts. Am J Physiol Lung Cell Mol Physiol 2005, 288: L43-L51

25. Boucherat O, Franco-Montoya ML, Thibault C, Incitti R, ChailleyHeu B, Delacourt C, Bourbon JR: Gene expression profiling in lung fibroblasts reveals new players in alveolarization. Physiol Genomics 2007, 32:128-141

26. Emblom-Callahan MC, Chhina MK, Shlobin OA, Ahmad S, Reese ES, Iyer EP, Cox DN, Brenner R, Burton NA, Grant GM, Nathan SD: Genomic phenotype of non-cultured pulmonary fibroblasts in idiopathic pulmonary fibrosis. Genomics 2010, 96: $134-145$

27. Yang S, Cui H, Xie N, Icyuz M, Banerjee S, Antony VB, Abraham E, Thannickal VJ, Liu G: miR-145 regulates myofibroblast differentiation and lung fibrosis. FASEB J 2013, 27:2382-2391

28. Hemmi H, Takeuchi O, Kawai T, Kaisho T, Sato S, Sanjo H, Matsumoto M, Hoshino K, Wagner H, Takeda K, Akira S: A Toll-like receptor recognizes bacterial DNA. Nature 2000, 408: $740-745$

29. Latz E, Schoenemeyer A, Visintin A, Fitzgerald KA, Monks BG, Knetter CF, Lien E, Nilsen NJ, Espevik T, Golenbock DT: TLR9 signals after translocating from the ER to CpG DNA in the lysosome. Nat Immunol 2004, 5:190-198

30. Zhang Q, Raoof M, Chen Y, Sumi Y, Sursal T, Junger W, Brohi K, Itagaki K, Hauser CJ: Circulating mitochondrial DAMPs cause inflammatory responses to injury. Nature 2010, 464:104-107

31. Oka T, Hikoso S, Yamaguchi O, Taneike M, Takeda T, Tamai T, Oyabu J, Murakawa T, Nakayama H, Nishida K, Akira S, Yamamoto A, Komuro I, Otsu K: Mitochondrial DNA that escapes from autophagy causes inflammation and heart failure. Nature 2012, 485:251-255

32. Meneghin A, Choi ES, Evanoff HL, Kunkel SL, Martinez FJ, Flaherty KR, Toews GB, Hogaboam CM: TLR9 is expressed in idiopathic interstitial pneumonia and its activation promotes in vitro myofibroblast differentiation. Histochem Cell Biol 2008, 130: 979-992

33. Hecker L, Jagirdar R, Jin T, Thannickal VJ: Reversible differentiation of myofibroblasts by MyoD. Exp Cell Res 2011, 317:1914-1921

34. Prasad S, Hogaboam CM, Jarai G: Deficient repair response of IPF fibroblasts in a co-culture model of epithelial injury and repair. Fibrogenesis Tissue Repair 2014, 7:7

35. Sato H, Takino T, Okada Y, Cao J, Shinagawa A, Yamamoto E, Seiki M: A matrix metalloproteinase expressed on the surface of invasive tumour cells. Nature 1994, 370:61-65

36. Kuznik A, Bencina M, Svajger U, Jeras M, Rozman B, Jerala R: Mechanism of endosomal TLR inhibition by antimalarial drugs and imidazoquinolines. J Immunol 2011, 186:4794-4804

37. Rutz M, Metzger J, Gellert T, Luppa P, Lipford GB, Wagner H, Bauer S: Toll-like receptor 9 binds single-stranded CpG-DNA in a sequence- and pH-dependent manner. Eur J Immunol 2004, 34: $2541-2550$

38. Sanjuan MA, Rao N, Lai KT, Gu Y, Sun S, Fuchs A, FungLeung WP, Colonna M, Karlsson L: CpG-induced tyrosine phosphorylation occurs via a TLR9-independent mechanism and is required for cytokine secretion. J Cell Biol 2006, 172: $1057-1068$

39. Bechtel W, Zeisberg M: Twist: a new link from hypoxia to fibrosis. Kidney Int 2009, 75:1255-1256

40. Chettimada S, Joshi SR, Alzoubi A, Gebb SA, McMurtry IF, Gupte R, Gupte SA: Glucose-6-phosphate dehydrogenase plays a 
critical role in hypoxia-induced $\mathrm{CD} 133+$ progenitor cells selfrenewal and stimulates their accumulation in the lungs of pulmonary hypertensive rats. Am J Physiol Lung Cell Mol Physiol 2014, 307:L545-L556

41. Higgins DF, Kimura K, Bernhardt WM, Shrimanker N, Akai Y, Hohenstein B, Saito Y, Johnson RS, Kretzler M, Cohen CD, Eckardt K-U, Iwano M, Haase VH: Hypoxia promotes fibrogenesis in vivo via HIF-1 stimulation of epithelial-to-mesenchymal transition. J Clin Invest 2007, 117:3810-3820

42. Eul B, Rose F, Krick S, Savai R, Goyal P, Klepetko W, Grimminger F, Weissmann N, Seeger W, Hänze J: Impact of HIF1alpha and HIF-2alpha on proliferation and migration of human pulmonary artery fibroblasts in hypoxia. FASEB J 2006, 20:163-165

43. Ahmad A, Ahmad S, Malcolm KC, Miller SM, Hendry-Hofer T, Schaack JB, White CW: Differential regulation of pulmonary vascular cell growth by hypoxia-inducible transcription factor-1alpha and hypoxia-inducible transcription factor-2alpha. Am J Respir Cell Mol Biol 2013, 49:78-85

44. Holmquist-Mengelbier L, Fredlund E, Löfstedt T, Noguera R, Navarro S, Nilsson H, Pietras A, Vallon-Christersson J, Borg A, Gradin K, Poellinger L, Påhlman S: Recruitment of HIF-1alpha and HIF-2alpha to common target genes is differentially regulated in neuroblastoma: HIF-2alpha promotes an aggressive phenotype. Cancer Cell 2006, 10:413-423

45. Maranchie JK, Vasselli JR, Riss J, Bonifacino JS, Linehan WM, Klausner RD: The contribution of VHL substrate binding and HIF1alpha to the phenotype of VHL loss in renal cell carcinoma. Cancer Cell 2002, 1:247-255

46. Kondo K, Kim WY, Lechpammer M, Kaelin WG Jr: Inhibition of HIF2alpha is sufficient to suppress pVHL-defective tumor growth. PLoS Biol 2003, 1:E83

47. Kondo K, Klco J, Nakamura E, Lechpammer M, Kaelin WG Jr: Inhibition of HIF is necessary for tumor suppression by the von HippelLindau protein. Cancer Cell 2002, 1:237-246

48. Rankin EB, Rha J, Unger TL, Wu CH, Shutt HP, Johnson RS, Simon MC, Keith B, Haase VH: Hypoxia-inducible factor-2 regulates vascular tumorigenesis in mice. Oncogene 2008, 27: $5354-5358$

49. Malhotra R, Lin Z, Vincenz C, Brosius FC 3rd: Hypoxia induces apoptosis via two independent pathways in Jurkat cells: differential regulation by glucose. Am J Physiol Cell Physiol 2001, 281: C1596-C1603

50. Todor A, Sharov VG, Tanhehco EJ, Silverman N, Bernabei A, Sabbah HN: Hypoxia-induced cleavage of caspase-3 and DFF45/ICAD in human failed cardiomyocytes. Am J Physiol Heart Circ Physiol 2002, 283:H990-H995

51. Egeblad M, Werb Z: New functions for the matrix metalloproteinases in cancer progression. Nat Rev Cancer 2002, 2:161-174

52. Zarrabi K, Dufour A, Li J, Kuscu C, Pulkoski-Gross A, Zhi J, Hu Y, Sampson NS, Zucker S, Cao J: Inhibition of matrix metalloproteinase 14 (MMP-14)-mediated cancer cell migration. J Biol Chem 2011, 286:33167-33177

53. Garcia-Alvarez J, Ramirez R, Sampieri CL, Nuttall RK, Edwards DR, Selman M, Pardo A: Membrane type-matrix metalloproteinases in idiopathic pulmonary fibrosis. Sarcoidosis Vasc Diffuse Lung Dis 2006, 23:13-21

54. Selman M, Ruiz V, Cabrera S, Segura L, Ramirez R, Barrios R, Pardo A: TIMP-1, $-2,-3$, and -4 in idiopathic pulmonary fibrosis: a prevailing nondegradative lung microenvironment? Am J Physiol Lung Cell Mol Physiol 2000, 279:L562-L574

55. Rowe RG, Keena D, Sabeh F, Willis AL, Weiss SJ: Pulmonary fibroblasts mobilize the membrane-tethered matrix metalloprotease, MT1-MMP, to destructively remodel and invade interstitial type I collagen barriers. Am J Physiol 2011, 301:L683-L692

56. Hogaboam CM, Murray L, Martinez FJ: Epigenetic mechanisms through which Toll-like receptor-9 drives idiopathic pulmonary fibrosis progression. Proc Am Thorac Soc 2012, 9:172-176
57. Suganuma H, Sato A, Tamura R, Chida K: Enhanced migration of fibroblasts derived from lungs with fibrotic lesions. Thorax 1995, 50: 984-989

58. White ES, Thannickal VJ, Carskadon SL, Dickie EG, Livant DL, Markwart S, Toews GB, Arenberg DA: Integrin alpha4betal regulates migration across basement membranes by lung fibroblasts: a role for phosphatase and tensin homologue deleted on chromosome 10. Am J Respir Crit Care Med 2003, 168:436-442

59. Pardo A, Selman M: Matrix metalloproteases in aberrant fibrotic tissue remodeling. Proc Am Thorac Soc 2006, 3:383-388

60. Merrell MA, Ilvesaro JM, Lehtonen N, Sorsa T, Gehrs B, Rosenthal E, Chen D, Shackley B, Harris KW, Selander KS: Toll-like receptor 9 agonists promote cellular invasion by increasing matrix metalloproteinase activity. Mol Cancer Res 2006, 4:437-447

61. Lim EJ, Lee SH, Lee JG, Kim JR, Yun SS, Baek SH, Lee C: Toll-like receptor 9 dependent activation of MAPK and NF-kB is required for the $\mathrm{CpG}$ ODN-induced matrix metalloproteinase-9 expression. Exp Mol Med 2007, 39:239-245

62. Ilvesaro JM, Merrell MA, Swain TM, Davidson J, Zayzafoon M, Harris KW, Selander KS: Toll like receptor-9 agonists stimulate prostate cancer invasion in vitro. Prostate 2007, 67:774-781

63. Ilvesaro JM, Merrell MA, Li L, Wakchoure S, Graves D, Brooks S, Rahko E, Jukkola-Vuorinen A, Vuopala KS, Harris KW, Selander KS: Toll-like receptor 9 mediates CpG oligonucleotideinduced cellular invasion. Mol Cancer Res 2008, 6:1534-1543

64. Pardo A, Gibson K, Cisneros J, Richards TJ, Yang Y, Becerril C, Yousem S, Herrera I, Ruiz V, Selman M, Kaminski N: Up-regulation and profibrotic role of osteopontin in human idiopathic pulmonary fibrosis. PLoS Med 2005, 2:e251

65. Weber GF, Ashkar S, Glimcher MJ, Cantor H: Receptor-ligand interaction between CD44 and osteopontin (Eta-1). Science 1996, 271:509-512

66. Denhardt DT, Noda M, O'Regan AW, Pavlin D, Berman JS: Osteopontin as a means to cope with environmental insults: regulation of inflammation, tissue remodeling, and cell survival. J Clin Invest 2001, 107:1055-1061

67. O'Regan A, Berman JS: Osteopontin: a key cytokine in cell-mediated and granulomatous inflammation. Int J Exp Pathol 2000, 81:373-390

68. Takahashi F, Takahashi $\mathrm{K}$, Okazaki $\mathrm{T}$, Maeda $\mathrm{K}$, Ienaga $\mathrm{H}$, Maeda M, Kon S, Uede T, Fukuchi Y: Role of osteopontin in the pathogenesis of bleomycin-induced pulmonary fibrosis. Am J Respir Cell Mol Biol 2001, 24:264-271

69. Thannickal VJ, Horowitz JC: Evolving concepts of apoptosis in idiopathic pulmonary fibrosis. Proc Am Thorac Soc 2006, 3:350-356

70. Tzouvelekis A, Harokopos V, Paparountas T, Oikonomou N, Chatziioannou A, Vilaras G, Tsiambas E, Karameris A, Bouros D, Aidinis V: Comparative expression profiling in pulmonary fibrosis suggests a role of hypoxia-inducible factor-1alpha in disease pathogenesis. Am J Respir Crit Care Med 2007, 176:1108-1119

71. Robinson CM, Neary R, Levendale A, Watson CJ, Baugh JA: Hypoxia-induced DNA hypermethylation in human pulmonary fibroblasts is associated with Thy-1 promoter methylation and the development of a pro-fibrotic phenotype. Respir Res 2012, 13:74

72. Ewald SE, Lee BL, Lau L, Wickliffe KE, Shi GP, Chapman HA, Barton GM: The ectodomain of Toll-like receptor 9 is cleaved to generate a functional receptor. Nature 2008, 456:658-662

73. Park B, Brinkmann MM, Spooner E, Lee CC, Kim YM, Ploegh HL: Proteolytic cleavage in an endolysosomal compartment is required for activation of Toll-like receptor 9. Nat Immunol 2008, 9:1407-1414

74. Matsumoto F, Saitoh S, Fukui R, Kobayashi T, Tanimura N, Konno K, Kusumoto Y, Akashi-Takamura S, Miyake K: Cathepsins are required for Toll-like receptor 9 responses. Biochem Biophys Res Commun 2008, 367:693-699

75. Yasuda K, Richez C, Uccellini MB, Richards RJ, Bonegio RG, Akira S, Monestier M, Corley RB, Viglianti GA, MarshakRothstein A, Rifkin IR: Requirement for DNA CpG content in TLR9- 
dependent dendritic cell activation induced by DNA-containing immune complexes. J Immunol 2009, 183:3109-3117

76. Means TK, Latz E, Hayashi F, Murali MR, Golenbock DT, Luster AD: Human lupus autoantibody-DNA complexes activate DCs through cooperation of CD32 and TLR9. J Clin Invest 2005, 115: 407-417

77. Boule MW, Broughton C, Mackay F, Akira S, Marshak-Rothstein A, Rifkin IR: Toll-like receptor 9-dependent and -independent dendritic cell activation by chromatin-immunoglobulin G complexes. J Exp Med 2004, 199:1631-1640
78. Lande R, Gregorio J, Facchinetti V, Chatterjee B, Wang YH, Homey B, Cao W, Wang YH, Su B, Nestle FO, Zal T, Mellman I, Schroder JM, Liu YJ, Gilliet M: Plasmacytoid dendritic cells sense self-DNA coupled with antimicrobial peptide. Nature 2007, 449:564-569

79. Vancheri C, Failla M, Crimi N, Raghu G: Idiopathic pulmonary fibrosis: a disease with similarities and links to cancer biology. Eur Respir J 2010, 35:496-504

80. Takahashi K, Sugi Y, Hosono A, Kaminogawa S: Epigenetic regulation of TLR4 gene expression in intestinal epithelial cells for the maintenance of intestinal homeostasis. J Immunol 2009, 183:6522-6529 